\title{
The Effects of Forest Residual Debris Disposal on Perennial Grass Emergence, Growth, and Survival in a Ponderosa Pine Ecotone
}

\author{
Darin J. Law ${ }^{1}$ and Peter F. Kolb ${ }^{2}$ \\ Authors are ${ }^{1}$ Postdoctoral Researcher, USDA Forest Service Rocky Mountain Research Station, 333 Broadway SE, Suite 115, Albuquerque, NM 87102- \\ 3497; and ${ }^{2}$ Associate Professor, Extension Forestry, Montana State University, 32 Campus Drive, Missoula, MT 59812.
}

\begin{abstract}
Soil surface conditions can have profound effects on plant seedling emergence and subsequent seedling survival. To test the hypothesis that different soil-surface treatments with logging residue affect range grass seedling emergence and survival, 6 alternative forest-residual treatments were established in the summer of 1998 following thinning of mature trees from approximately 500 to 133 trees $\cdot \mathrm{ha}^{-1}$. The treatments included 1) whole logging debris, hand-piled; 2) whole logging-debris piles that were burned; 3) whole logging-debris piles that were chipped; 4) whole logging-debris piles that were chipped and burned; 5) scattered debris followed by a broadcast burn; and 6) zero debris, not burned. The influences of the debris treatments on grass seedling emergence and survival were tested by seeding with native and exotic perennial grass species. Three plots per treatment were seeded with a mix of 4 native grass species, and another 3 plots per treatment were seeded with a mix of 4 exotic grass species. Two plots per treatment were left unseeded. Subsequent grass emergence, growth, and establishment were measured as seedling emergence, cover, density, height, and biomass for 3 growing seasons. Grass cover, density height, and biomass increased on the burn treatments during the study. Less-significant results were obtained for the nonburned woodydebris treatments. In addition, important abiotic factors, such as soil moisture and soil surface temperature, were not adversely affected by the woody debris disposal practices tested in this study. Results indicate that scattered woody debris that is broadcast burned is the best mechanism for disposing of woody debris, increasing grass emergence and survival, and preventing ponderosa pine recruitment and exotic invasion.
\end{abstract}

\begin{abstract}
Resumen
Las condiciones de la superficie del suelo pueden tener profundos efectos en la emergencia y supervivencia de las plántulas. Para probar la hipótesis de que diferentes tratamientos de la superficie del suelo con residuos de tala del bosque afecta la emergencia y supervivencia de los zacates del pastizal se establecieron 6 tratamientos con residuos forestales, los cuales se aplicaron en el verano de 1998 posterior al aclareo de árboles maduros de aproximadamente 500 a 133 árboles $\cdot$ ha $^{-1}$. Los tratamientos evaluados fueron 1) residuos de madera enteros apilados manualmente, 2) pilas de residuos de madera enteros que se quemaron, 3) pilas de residuos de madera desmenuzados, 4) pilas de residuos de madera enteros desmenuzados y quemados, 5) residuos de madera esparcidos seguido de una quema y 6) sin residuos ni quema. Las influencias de los tratamientos de residuos en la emergencia y supervivencia de las plántulas de los zacates fueron evaluadas sembrando especies perennes de zacates nativos y exóticos. Se sembraron 3 parcelas por tratamiento con una mezcla de 4 especies nativas y otras 3 con una mezcal de 4 especies exóticas y 2 parcelas por tratamiento se dejaron sin sembrar. Se midieron la emergencia, establecimiento y crecimiento de las plántulas conforme emergieron y la cobertura, densidad, altura y biomasa durante 3 estaciones de crecimiento. Durante el estudio, la cobertura, densidad, altura y biomasa se incrementaron en los tratamientos con quema. Con los tratamientos con residuos de madera se obtuvieron resultados menos significativos. Además, importantes factores abióticos como la humedad del suelo y la temperatura de la superficie del suelo no fueron afectados adversamente por las prácticas de aplicación de los residuos de madera probadas en este estudio. Los resultados indican que esparcir residuos de madera y quemarlos es el mejor mecanismo para incrementar la emergencia y supervivencia de los zacates y prevenir el establecimiento del pino ponderosa y las invasiones de especies exóticas.
\end{abstract}

Key Words: fire, open savanna ecosystem, restoration, seedbed, woody debris disposal

\section{INTRODUCTION}

Interspecific competition plays a key role in the natural distributions of species (Caldwell et al. 1985; Metcalfe et al.

Funding support was provided by a grant from McIntire-Stennis through Montana State Forest and Conservation Experiment Station, Rocky Mountain Research Station Albuquerque Lab, and Cathy Campbell of the Hilger Hereford Ranch (P. F. K.)

At the time of the research, Law was a graduate student, College of Forestry and Conservation, University of Montana, Missoula, MT.

Correspondence: Darin Law, US Dept of Agriculture, Forest Service, Rocky Mountain Research Station, 333 Broadway SE, Suite 115, Albuquerque, NM 87102-3497. Email: djlaw@fs.fed.us

Manuscript received 15 March 2006; manuscript accepted 17 August 2007.
1986; Ellison 1987; Eissenstat and Caldwell 1988; Bertness 1991a, 1991b; Pennings and Callaway 1992). Reductions in resource supply, such as soil water, likely increase competition intensity, whereas factors that increase resource supply lower competition intensity (Davis et al. 1998). In semiarid and arid ecosystems of the southwestern United States, competition for soil moisture can influence plant community composition (Fonteyn and Mahall 1981; Robberecht et al. 1983; Allen and Allen 1986; Davis et al. 1998). Fibrous root systems of grasses are often better competitors for moisture in upper soil horizons than seedlings with woody root systems (Vance and Running 1985; Eissenstat and Caldwell 1988; Kolb and 
Robberecht 1996). For example, Eissenstat and Caldwell (1988) reported that competition for soil water between desert wheatgrass (Agropyron desertorum Linn.) and Wyoming big sagebrush (Artemisia tridentata subsp. wyomingensis Beetle and Young) seedlings in the Great Basin in late May resulted in $55 \%$ mortality of the latter. In another study, $60 \%$ of antelope bitterbrush (Purshia tridentata Pursh.) seedlings died in a seeded crested wheatgrass (Agropyron cristatum [L.] Gaertn.) community because of water stress (Hubbard 1957).

Competition for soil moisture between established bunchgrass communities and conifer seedlings can greatly reduce conifer seedling survival (Griffin 1982; Vance and Running 1985; Kolb and Robberecht 1996). Ponderosa pine (Pinus ponderosa P. \& C. Lawson) seedlings growing in a bluebunch wheatgrass (Pseudoroegneria spicata [Pursh] Scribn. \& Smith) community exhibited nearly $100 \%$ mortality in the first 4 months of growth, whereas the exclusion of bluebunch wheatgrass roots from a 0.15 - and 0.30 -m-deep root zone decreased pine seedling mortality by $40 \%$ and $80 \%$, respectively (Kolb and Robberecht 1996). Although ponderosa pine root growth is quite rapid compared with other conifers and can extend below competitor's roots (Daubenmire 1968; Kolb and Robberecht 1996), available soil moisture in upper horizons may be depleted by other vegetation before ponderosa pine roots can grow sufficiently deep. Therefore, it seems probable that reestablishing competitive grasses on sites previously inhabited by conifer thickets would greatly reduce the likelihood of new conifer seedling establishment and survival.

Mechanical reduction of conifer densities on rangeland often results in a large amount of woody debris (Fule et al. 2001) that is generally disposed of by chipping, scattering, or burning. Little is known about the effects of woody debris-disposal practices on grass germination and seedling survival. Soilsurface moisture is an important determinant of seed germination (Koller 1972; Raynal and Bazzaz 1973; Lauenroth et al. 1994) and can be both positively and negatively affected by soil-surface debris. In both grasslands and old fields, the presence of litter on the soil surface has been shown to increase soil water content by increasing infiltration and decreasing temperature, evaporation, and runoff (Dyksterhuis and Shmutz 1947; Gupta et al. 1984; Phillips and Phillips 1984). Conversely, litter can intercept rainfall, increasing evaporative losses before being absorbed into the soil (Weaver and Rowland 1952; Walsh and Voigt 1977; Sala and Lauenroth 1982).

The effects of debris-consuming fires can also alter the soilwater balance by influencing water infiltration, water repellency, and the porosity of the soil surface (Mallik et al. 1984). Ash generated by burned organic matter can have a lower albedo than bare mineral soil, which can cause an increase in the soil surface temperature and possibly cause the soil to dry faster (Mallik et al. 1988; Herr et al. 1999). On the other hand, increased nitrogen availability following fire may improve site productivity (DeLuca and Zouhar 2000). Also, the incorporation of ash into a coarse soil surface may increase soil water-holding capacity.

Effective treatments are needed to create a natural balance between tree and grass dominance that will restore historically open savanna ecosystems. Increased soil water, as an effect from logging debris, may reduce interspecific competition, enhancing conifer seedling establishment (Gruell et al. 1986; Arno 1996; Bolen 1998; Davis et al. 1998). Alternatively, increased moisture may enhance grass germination on sites manipulated with residual woody debris and seeded with competitive grass species. Increased grass dominance should increase competition intensity and so reduce conifer seedling reestablishment and survival, facilitating range restoration. The objective of this study was to compare the effectiveness of various woody debris disposal practices, both burned and unburned, on seeded grass germination and survival. Additionally, we examined the effects of woody debris disposal on naturally occurring ponderosa pine recruitment. We hypothesized that a combination of woody debris and fire would enhance grass germination and seedling survival.

\section{METHODS}

\section{Study Area}

The study site is a low-productive ponderosa pine site typical of the semiarid short-grass prairie common to central Montana. The study site was $30 \mathrm{~km}$ north of Helena, Montana, on the Hilger Hereford Ranch, Lewis and Clark County (lat $46^{\circ} 49^{\prime} 30^{\prime \prime} \mathrm{N}$; long $112^{\circ} 13^{\prime} 30^{\prime \prime} \mathrm{W}$; mean elevation $=1463 \mathrm{~m}$ ). On average, there are 110-115 frost-free days, and the mean annual temperature is $5^{\circ} \mathrm{C}$, with summer maximum temperatures averaging $22^{\circ} \mathrm{C}$ and minimum winter temperatures averaging $-6^{\circ} \mathrm{C}$. Mean annual precipitation is $278 \mathrm{~mm}$ and mostly occurs from April through June. Weather data were provided from the weather station at Holter Dam, Montana, which was $20 \mathrm{~km}$ north of the study site at an elevation of $1064 \mathrm{~m}$ (Western Regional Climate Center, Reno, NV). Soils were shallow $(20-40 \mathrm{~cm})$ Entisols from $A B$ belt series Algonkian rocks. Soil texture was a gravelly silt loam with $25 \%$ coarse fragments. The soil surface consisted of $60 \%$ fragmented rock interspersed with small patches of finertextured sand and silt. The study site was located on a $15 \%$ slope with a southeast aspect.

\section{Treatments}

In summer and fall 1998, the trees on the 1-ha site were thinned from a mean of 500 to 133 trees $\cdot \mathrm{ha}^{-1}$. Ponderosa pine was the only tree species on the study site and ranged in size from seedling/sapling to mature $38 \mathrm{~cm}$ in diameter at breast height. The trees were thinned from below, so the overstory, mature trees were retained at 133 trees $\cdot \mathrm{ha}^{-1}$. The residual logging debris was used to establish 48 research plots separated by at least 5-10 m. Six soil surface treatments that were $2 \times 2 \mathrm{~m}$ in size were randomly applied to the 48 plots and replicated 8 times. Plots were further subdivided into 3 seeding treatments. Each research plot was fenced with 1-m-high livestock fence to prevent herbivory from cattle. Deer and elk were still able to access the plots, but according to our observations, their influence was minimal. The debris treatments were as follows:

1) whole logging debris, hand-piled, $1 \mathrm{~m}$ high by $2 \mathrm{~m}$ in diameter

2) treatment (1) that was burned

3) treatment (1) that was chipped with a mechanical flail 
4) treatment (1) that was chipped and burned

5) scattered debris followed by a broadcast burn

6) zero debris, not burned

The pile treatments were $1 \mathrm{~m}$ high by $2 \mathrm{~m}$ in diameter to maintain fire control. The chips for the chipped treatment were uniformly scattered and accumulated an average ground-cover thickness of $10 \mathrm{~cm}$. The scattered debris was a typical lop-andscatter method commonly used by timber managers. The burning took place in the fall of 1998 with drip torches and was heavily guarded so that the fire did not spread from the designated research plot. The burning went as planned, producing a range of soil surface conditions. The broadcast burn and the chip-with-burn treatments were both incomplete burns, whereas the pile-with-burn treatments had complete woody-debris consumption.

Eight commonly used perennial dry-land range grasses composed of 2 mixtures with 4 species each (Table 1) were broadcast-seeded on the soil surface treatments in December 1998. Three plots per treatment were seeded with a native grass mix, and 3 were seeded with an exotic grass mix. Two plots per treatment were left unseeded as controls.

\section{Vegetation Measurements}

Grass seeding success was measured monthly during the 1999, 2000, and 2001 growing seasons. Typically, grass seedlings are considered established after they have begun to photosynthesize sufficiently to exist and grow independent of their seed reserves (Harper 1977; Lincoln et al. 1982). Grass seeding success or establishment was measured as grass seedling emergence, cover, culm density, height, and biomass. Grass seedlings greater than $5 \mathrm{~cm}$ tall and containing more than one slender culm were not considered to be recently emerged. Therefore, grass that emerged in May was not counted in August, unless it remained $<5 \mathrm{~cm}$ tall and had only one slender culm. Grass establishment was determined by measuring cover, culm density, and height at monthly intervals, and biomass at the end of each growing season. Grass cover, by species, was measured via the Daubenmire (1959) cover-class method using 4 frames $(0.25 \times 0.25 \mathrm{~m})$ within each plot. Grass seedling emergence and grass culm density, by species, was measured by counting each seedling and grass culm within the cover frames. Grass height for each species was measured in each cover frame using a metric ruler. At the end of each growing season, when the grasses were dormant, annual aboveground production was measured for each species by clipping at $5 \mathrm{~cm}$ above ground level and weighing the biomass as described by Bonham (1989). The number of naturally occurring ponderosa pine seedlings was counted monthly in the cover frames. Mean ponderosa pine recruitment was calculated as the mean number of seedlings per square meter in 2001 less the mean number of seedlings per square meter in 1999.

\section{Soil Moisture}

Soil moisture was measured by extracting soil samples with a cylindrical soil probe $(2 \mathrm{~cm}$ in diameter and $60 \mathrm{~cm}$ long). Three soil samples per plot were taken from a depth of $0-5 \mathrm{~cm}$ along an uphill transect separated by $20 \mathrm{~cm}$. Each sample was transported in a sealed specimen cup to the soil lab at the
Table 1. Perennial grasses used in each of the 2 seed Sixtures.

\begin{tabular}{|c|c|c|}
\hline Grass seeds & $\%$ seed in mix & Seeds $\cdot \mathrm{m}^{-2}$ \\
\hline \multicolumn{3}{|l|}{ Native grass mix } \\
\hline $\begin{array}{l}\text { 'Secar' bluebunch wheatgrass } \\
\text { (Pseudoroegneria spicata [Pursh] } \\
\text { Scribn. \& Smith) }\end{array}$ & 36 & 374 \\
\hline $\begin{array}{l}\text { Mountain brome (Bromus } \\
\text { marginatus Nees ex Steud.) }\end{array}$ & 32 & 168 \\
\hline Sheep fescue (Festuca ovina L.) & 17 & 857 \\
\hline $\begin{array}{l}\text { Slender wheatgrass (Elymus } \\
\text { trachycaulus [Link] Gould ex } \\
\text { Shinners) }\end{array}$ & 15 & 177 \\
\hline \multicolumn{3}{|l|}{ Exotic grass mix } \\
\hline $\begin{array}{l}\text { Intermediate wheatgrass } \\
\text { (Thinopyrum intermedium [Host] } \\
\text { Barkworth \& D. R. Dewey) }{ }^{1}\end{array}$ & 35 & 228 \\
\hline $\begin{array}{l}\text { 'Nordan' desert wheatgrass } \\
\text { (Agropyron desertorum [Fisch. ex } \\
\text { Link] J. A. Schultes) }\end{array}$ & 30 & 389 \\
\hline $\begin{array}{l}\text { Pubescent wheatgrass } \\
\text { (Agropyron pubescens Elmer) }^{1}\end{array}$ & 25 & 185 \\
\hline $\begin{array}{l}\text { Russian wildrye (Psathyrostachys } \\
\text { juncea [Fisch.] Nevski) }\end{array}$ & 10 & 130 \\
\hline
\end{tabular}

${ }^{1}$ Pubescent wheat grass has since been combined with intermediate wheatgrass as Thinopyrum intermedium, but for the purposes of this article, the 2 grasses will remain separate.

College of Forestry and Conservation, University of Montana (Missoula, MT), where gravimetric analysis was performed. Following the procedure in Gardner (1986), samples were dried for 24 hours at $105^{\circ} \mathrm{C}$ to determine water content. Water release curves were established using a Decagon WP4 dewpoint PotentiaMeter (Decagon Devices, Inc, Pullman, WA). Water was added to 70 oven-dried soil samples from the burn and debris treatments to achieve a water content between $1 \%$ and $10 \%$. Water potential was then measured and correlated with the equivalent percentage of moisture to create waterrelease curves for the treatments.

\section{Soil Surface Temperature}

Soil surface temperatures were measured during the 2001 growing season on each plot using a Rayorger ST 800 (Raytech Corp, Phoenix, AZ) infrared thermometer. Measurements were taken at a distance of $1 \mathrm{~m}$ from the soil surface, which resulted in an average temperature reading for a $3-\mathrm{cm}$-diameter circle. Three measurements were taken, at the edge, center, and halfway between the edge and center of each plot, once a month from June through August at 0600, 1200, and 1800 hours.

\section{Statistical Analyses}

A repeated-measures analysis of variance (ANOVA) across years and months was used to test the differences among treatments at $\alpha=0.05$. The means for grass cover, density, and height are growing-season averages for 3 growing seasons. When necessary, dependent variables were log-transformed to meet homogeneity of variance and normality assumptions of 
ANOVA analysis but the data were retransformed according to Duan (1983) for the tables and graph. When normality and homogeneity of variance assumptions of ANOVA could not be met, the Friedman's nonparametric test (Benard and van Elteren 1953; Mack and Skillings 1980; Norwood et al. 1989; Hollander and Wolfe 1999) was used to identify significance. Each table showing data analyzed via the Friedman's nonparametric test are shown without standard errors as standard errors are not produced in the results of a Friedman's test. Conventional $t$ tests were used to determine significance among the individual seeded species. Adjusted linear contrasts were used to identify differences among the means. All of the tests used were declared significant at $P \leq 0.05$. All analyses were performed using GLIMMIX or MIXED procedures of SAS V. 9.1, and Friedman's tests were performed using a Microsoft Excel macro written by US Department of Agriculture Forest Service Rocky Mountain Research Station statistician Dr Rudy King. It is important to note that 2 controls were considered for the analyses. All interactions between the seed mixes and the treatments were tested. When significant interactions occurred between the seed mixes and the treatments, then the control became the zero debris, notburned and not-seeded treatment. When no significant interactions were found between the treatments and the seed mixes, then seed mix became irrelevant, and the control became the zero debris and not-burned treatment.

\section{RESULTS}

\section{Grass Emergence}

Grass seedling emergence was highest in 1999 occurring throughout the growing season (Table 2) but dramatically diminished in 2000 and 2001. Only the data from 1999 are presented here. Very little emergence occurred in the nonseeded treatment plots. Emergence that differed significantly from the control occurred only in the native-seeded, chip-with-burn treatment. In August 1999, the native-seeded, chip-with-burn treatment had 65.68 grass seedlings $\cdot \mathrm{m}^{-2}$, whereas the control had zero.

\section{Grass Growth and Survival (Establishment)}

Grass Cover. Initially, most of the treatments significantly reduced grass cover (Table 3), but the interaction between seed mix and treatment was significant. In 1999, the control treatment (zero debris, not burned and not seeded) averaged $19.49 \%$ cover. That same year, all of the not-seeded treatments averaged only $2.22 \%$ grass cover. Alternatively, the chip-withburn treatment and the zero debris and not-burned treatment seeded with both mixes did not differ from the control with an average grass cover of $7.20 \%$ and $10.99 \%$, respectively. The rest of the seeded treatments averaged less cover than the control with $3.67 \%$.

Two years after treatment (2000), grass cover on the burned treatments that were seeded with both mixes did not differ from the control—not seeded, zero debris and not-burned treatment $(17.87 \%$ grass cover $)$-with a high of $23.21 \%$ in the chip-with-burn treatment and a low of $10.54 \%$ in the pilewith-burn treatment. Grass cover on the pile treatment, whether seeded or not, remained significantly below the control, with an average grass cover of $2.29 \%$. Grass cover on the chip treatment did not differ from the control (not seeded, zero debris and not-burned treatment) except for the native-seeded chip treatment.

Three years after treatment (2001), the interaction between the seed mixes and the treatments was not significant, and seed mix became irrelevant in the statistical analysis. The chip treatment was the only treatment $(4.28 \%$ grass cover) that had significantly less grass cover than the control-zero debris and not-burned treatment $(12.21 \%$ grass cover). The rest of the treatments averaged $15.79 \%$ grass cover but did not differ from the control.

Grass Culm Density. Initially (1999), grass culm density was significantly diminished by the treatments regardless of seeding (Table 3). The control (zero debris and not-burned treatment) had a mean grass culm density of $330.41 \mathrm{culms} \cdot \mathrm{m}^{-2}$ in 1999. The rest of the treatments only averaged 25.35 culms $\cdot \mathrm{m}^{-2}$.

In the year 2000, seeding became an important factor in the statistical analysis because there was a significant interaction between the treatments and the seed mixes. Average grass culm density on the burned treatments that were seeded with either mix (121.06 culms $\cdot \mathrm{m}^{-2}$ ) did not differ from the control-zero debris, not-burned and not-seeded treatment (362.48 culms $\cdot \mathrm{m}^{-2}$ ) -whereas the burned treatments that were not seeded averaged less than the control $\left(14.67 \mathrm{culms} \cdot \mathrm{m}^{-2}\right)$. Although the chip treatment seeded with the exotic mix $(27.95$ culms $\cdot \mathrm{m}^{-2}$ ) did not differ from the control, for the most part, grass culm density on the nonburned woody-debris treatments averaged less than the control, with a mean density of 12.52 culms $\cdot \mathrm{m}^{-2}$.

Three years after burn (2001), seed mix became irrelevant in the statistical analysis (no treatment by seed mix interaction), and the burn treatments did not differ from the control regardless of the seeding (Table 3). The burn treatments averaged 135.37 culms $\cdot \mathrm{m}^{-2}$ compared with 186.22 culms $\cdot \mathrm{m}^{-2}$ in the control (zero debris and not-burned treatment). The woody-debris treatments remained less than the control, with an average grass culm density of 12.05 culms $\cdot \mathrm{m}^{-2}$.

Grass Height. Grass height was more responsive to the treatments and their seed mixes than cover and density. Mean grass height among the burn treatments 1 year after the burn $(9.72 \mathrm{~cm})$ did not differ from the control-not seeded, zero debris and not-burned treatment $(9.08 \mathrm{~cm})$-regardless of seeding (Table 4). Grass in the nonseeded woody-debris treatments was significantly taller than the grass in the control with a height of $27.74 \mathrm{~cm}$. Alternatively, grass height on the woody-debris treatments seeded with the exotic mix $(11.73 \mathrm{~cm})$ did not differ from the control. Grass height in the chip treatments seeded with the native mix $(9.21 \mathrm{~cm})$ was also not different from the control, but grass height on the pile treatments seeded with the native mix was an average of 17.84 $\mathrm{cm}$ taller than the control.

In 2000, 2 years postburn, almost all of the treatments had taller grass than the control. Grass in the burn treatments seeded with the exotic mix averaged $30.38 \mathrm{~cm}$, whereas the control only averaged $8.23 \mathrm{~cm}$. Grass on the broadcast-burn 
Table 2. Grass seedling emergence among the treatments on the Hilger Hereford ranch near Helena, Montana. Grass seedling density was analyzed via a Friedman's nonparametric analysis because the data did not meet the assumptions of ANOVA analysis. The Friedman's nonparametric test is a rank test and does not use the variance among the data to estimate significance. As a result, standard errors are not produced. Significant seedling growth is indicated by the bold number $(\alpha=0.05)$. Comparisons were made between treatments and the control (not seeded, zero debris, and not burned).

\begin{tabular}{|c|c|c|c|}
\hline $\begin{array}{l}\text { Treatment and } \\
\text { month }\end{array}$ & $\begin{array}{c}\text { Not sown } \\
\text { (seedlings } \cdot \mathrm{m}^{-2} \text { ) }\end{array}$ & $\begin{array}{l}\text { Exotic sown } \\
\text { (seedlings } \cdot \mathrm{m}^{-2} \text { ) }\end{array}$ & $\begin{array}{c}\text { Native sown } \\
\left(\text { seedlings } \cdot \mathrm{m}^{-2} \text { ) }\right.\end{array}$ \\
\hline \multicolumn{4}{|l|}{ June } \\
\hline Chip & 11.00 & 97.00 & 32.00 \\
\hline Pile & 5.52 & 31.52 & 0.00 \\
\hline Broadcast burn & 0.00 & 36.32 & 113.68 \\
\hline Chip with burn & 1.52 & 45.68 & 32.68 \\
\hline Pile with burn & 2.52 & 57.68 & 28.00 \\
\hline $\begin{array}{l}\text { Zero debris and not } \\
\text { burned }\end{array}$ & 37.00 & 32.68 & 6.00 \\
\hline $\begin{array}{l}\text { Zero debris not } \\
\text { burned and not } \\
\text { seeded (control) }\end{array}$ & 37.00 & 37.00 & 37.00 \\
\hline \multicolumn{4}{|l|}{ July } \\
\hline Chip & 0.00 & 110.00 & 4.32 \\
\hline Pile & 0.00 & 0.00 & 0.00 \\
\hline Broadcast burn & 1.52 & 22.32 & 61.32 \\
\hline Chip with burn & 2.52 & 62.00 & 86.32 \\
\hline Pile with burn & 0.00 & 36.68 & 4.00 \\
\hline $\begin{array}{l}\text { Zero debris and not } \\
\text { burned }\end{array}$ & 0.00 & 48.32 & 7.00 \\
\hline $\begin{array}{l}\text { Zero debris not } \\
\text { burned and not } \\
\text { seeded (control) }\end{array}$ & 0.00 & 0.00 & 0.00 \\
\hline \multicolumn{4}{|l|}{ August } \\
\hline Chip & 2.00 & 128.00 & 24.68 \\
\hline Pile & 0.00 & 7.52 & 0.00 \\
\hline Broadcast burn & 1.00 & 146.32 & 138.32 \\
\hline Chip with burn & 2.00 & 23.68 & 65.68 \\
\hline Pile with burn & 0.00 & 63.68 & 10.32 \\
\hline $\begin{array}{l}\text { Zero debris and not } \\
\text { burned }\end{array}$ & 0.00 & 135.92 & 105.32 \\
\hline $\begin{array}{l}\text { Zero debris not } \\
\text { burned and not } \\
\text { seeded (control) }\end{array}$ & 0.00 & 0.00 & 0.00 \\
\hline \multicolumn{4}{|l|}{ September } \\
\hline Chip & 0.00 & 53.68 & 17.00 \\
\hline Pile & 0.00 & 0.52 & 0.00 \\
\hline Broadcast burn & 0.00 & 5.68 & 52.32 \\
\hline Chip with burn & 1.00 & 0.00 & 10.68 \\
\hline Pile with burn & 0.00 & 10.20 & 1.00 \\
\hline $\begin{array}{l}\text { Zero debris and not } \\
\text { burned }\end{array}$ & 0.00 & 8.00 & 27.00 \\
\hline $\begin{array}{l}\text { Zero debris not } \\
\text { burned and not } \\
\text { seeded (control) }\end{array}$ & 0.00 & 0.00 & 0.00 \\
\hline
\end{tabular}

and chip-with-burn treatments seeded with the native mix averaged $15.12 \mathrm{~cm}$ taller than the control. Grass height on the woody debris treatments that were seeded with the exotic mix did not differ from the control, with an average height of $16.02 \mathrm{~cm}$. Alternatively, grass on the not-burned woody-debris treatments seeded with the native mix averaged $31.61 \mathrm{~cm}$ taller than the control, and the not-seeded woody-debris treatments averaged $23.77 \mathrm{~cm}$ taller.

Three years after the burn (2001), the only seeded-burn treatment that did not have grass taller than the control was the native-seeded pile-with-burn treatment. The other seeded-burn treatments had an average grass height of $38.99 \mathrm{~cm}$, which was $27.35 \mathrm{~cm}$ taller than the control. Grass on the seeded-pile treatments was on average $36.7 \mathrm{~cm}$ tall, which was $25.06 \mathrm{~cm}$ taller than the control. Grass in the not-seeded-chip treatment and the exotic-seeded-chip treatment had an average height of 37.50 and $30.86 \mathrm{~cm}$, which was 25.86 and $19.22 \mathrm{~cm}$ taller than the control, respectively.

Grass Biomass. In 1999, grass biomass was less than the control (zero debris, not burned and not seeded) only in the not-seeded chip-with-burn and pile-with-burn treatments, with an average grass biomass of $0.04 \mathrm{~g} \cdot \mathrm{m}^{-2}$, compared with the $9.80 \mathrm{~g} \cdot \mathrm{m}^{-2}$ in the control (Table 4). All of the other treatments did not differ from the control, with an average biomass of $3.42 \mathrm{~g} \cdot \mathrm{m}^{-2}$.

Two years after the burn (2000), the burn treatments did not differ from the control regardless of seeding with an average grass biomass of $16.52 \mathrm{~g} \cdot \mathrm{m}^{-2}$ compared with $11.23 \mathrm{~g} \cdot \mathrm{m}^{-2}$ in the control. The nonburned woody-debris treatments still had less biomass than the control, with an average of $4.92 \mathrm{~g} \cdot \mathrm{m}^{-2}$ compared with $11.23 \mathrm{~g} \cdot \mathrm{m}^{-2}$ on the control.

Finally, 3 years postburn (2001), the broadcast-burn treatment had an average grass biomass of $93.12 \mathrm{~g} \cdot \mathrm{m}^{-2}$ regardless of seeding, which was $73.12 \mathrm{~g} \cdot \mathrm{m}^{-2}$ higher than the control (zero debris and not burned). None of the other treatments differed from the control, with an average biomass of $36.27 \mathrm{~g} \cdot \mathrm{m}^{-2}$ compared with $20 \mathrm{~g} \cdot \mathrm{m}^{-2}$ for the control.

Individual grass species did not exhibit a significant association with one burn treatment over another, with the exception of mountain brome (Bromus marginatus Nees ex Steud.) and intermediate wheatgrass (Thinopyrum intermedium [Host] Barkworth \& D.R. Dewey). Mountain brome had nearly 7 times more biomass in the broadcast-burn treatment than in the pile-with-burn treatment (data not shown). Intermediate wheatgrass produced an average of 8 times more biomass in the pile-with-burn treatment compared with the other species, except desert wheatgrass (Agropyron desertorum [Fisch. ex Link] J. A. Schultes; data not shown). Neither Russian wildrye (Psathyrostachys juncea [Fisch.] Nevski) or sheep fescue (Festuca ovina L.) were detected at any time during the study.

Of the exotic grasses, desert wheatgrass, intermediate wheatgrass, and pubescent wheatgrass (Agropyron pubescens Elmer) seeded in the broadcast-burn and chip-with-burn treatments exceeded the zero-debris and not-burned treatment in biomass and cover during the study (data not shown). Of the native grasses, mountain brome and slender wheatgrass (Elymus trachycaulus [Link] Gould ex Shinners) seeded on the broadcast-burn and chip-with-burn treatments exceeded 
Table 3. Grass cover and density on the Hilger Hereford ranch near Helena, Montana. The bold numbers represent significant differences between the treatment and the control. If there was a significant interaction between the treatments and the seed mixes then the control was the not seeded, zero debris, and not burned treatment. If there was not a significant interaction between the treatments and the seed mixes then the control was the zero-debris and not-burned treatment $(\alpha=0.05)$.

\begin{tabular}{|c|c|c|c|c|c|c|}
\hline Treatment and year & $\begin{array}{l}\text { Not sown cover } \\
(\%)\end{array}$ & SE & $\begin{array}{c}\text { Exotic sown cover } \\
(\%)\end{array}$ & SE & $\begin{array}{c}\text { Native sown cover } \\
(\%)\end{array}$ & SE \\
\hline \multicolumn{7}{|l|}{1999} \\
\hline Chip & 3.84 & 1.65 & 4.00 & 1.31 & 2.72 & 1.27 \\
\hline Pile & 2.36 & 1.23 & 2.05 & 1.31 & 1.98 & 1.33 \\
\hline Broadcast burn & 1.70 & 0.99 & 4.40 & 0.71 & 4.89 & 0.73 \\
\hline Chip with burn & 1.72 & 3.67 & 6.75 & 2.10 & 7.64 & 2.22 \\
\hline Pile with burn & 1.47 & 1.67 & 6.35 & 1.04 & 2.99 & 0.84 \\
\hline Zero debris and not burned & 19.49 & 1.33 & 9.92 & 0.72 & 12.06 & 0.80 \\
\hline Zero debris not burned and not seeded (control) & 19.49 & 1.33 & 19.49 & 1.33 & 19.49 & 1.33 \\
\hline \multicolumn{7}{|l|}{2000} \\
\hline Chip & 3.03 & 2.05 & 3.86 & 1.60 & 2.73 & 1.58 \\
\hline Pile & 1.94 & 1.29 & 3.09 & 1.15 & 1.85 & 1.34 \\
\hline Broadcast burn & 2.95 & 0.33 & 11.72 & 0.47 & 13.98 & 0.52 \\
\hline Chip with burn & 2.97 & 3.43 & 23.21 & 5.51 & 15.80 & 4.32 \\
\hline Pile with burn & 3.09 & 2.06 & 15.70 & 3.04 & 10.54 & 2.41 \\
\hline Zero debris and not burned & 17.87 & 1.56 & 10.19 & 0.90 & 14.42 & 1.11 \\
\hline Zero debris not burned and not seeded (control) & 17.87 & 1.56 & 17.87 & 1.56 & 17.87 & 1.56 \\
\hline \multicolumn{7}{|l|}{2001 No treatment $\times$ seed mix interaction } \\
\hline Chip & 4.28 & 0.62 & & & & \\
\hline Pile & 5.76 & 1.04 & & & & \\
\hline Broadcast burn & 23.38 & 1.41 & & & & \\
\hline Chip with burn & 20.95 & 1.04 & & & & \\
\hline Pile with burn & 13.06 & 1.56 & & & & \\
\hline \multirow[t]{2}{*}{ Zero debris and not burned (control) } & 12.21 & 1.06 & & & & \\
\hline & $\begin{array}{l}\text { Density culms } \\
\qquad\left(\mathrm{m}^{-2}\right)\end{array}$ & SE & $\begin{array}{l}\text { Density culms } \\
\qquad\left(\mathrm{m}^{-2}\right)\end{array}$ & SE & $\begin{array}{l}\text { Density culms } \\
\qquad\left(\mathrm{m}^{-2}\right)\end{array}$ & SE \\
\hline \multicolumn{7}{|l|}{1999 No treatment $\times$ seed mix interaction } \\
\hline Chip & 31.95 & 10.12 & & & & \\
\hline Pile & 12.41 & 4.28 & & & & \\
\hline Broadcast burn & 34.13 & 7.42 & & & & \\
\hline Chip with burn & 27.91 & 6.73 & & & & \\
\hline Pile with burn & 20.35 & 3.21 & & & & \\
\hline Zero debris and not burned (control) & 330.41 & 20.38 & & & & \\
\hline \multicolumn{7}{|l|}{2000} \\
\hline Chip & 17.43 & 14.01 & 27.95 & 11.83 & 15.19 & 10.06 \\
\hline Pile & 9.21 & 6.48 & 12.37 & 6.15 & 8.42 & 6.78 \\
\hline Broadcast burn & 16.14 & 3.16 & 127.77 & 8.08 & 129.24 & 8.14 \\
\hline Chip with burn & 13.01 & 18.67 & 200.20 & 45.11 & 114.21 & 30.51 \\
\hline Pile with burn & 14.87 & 7.23 & 90.81 & 13.66 & 64.14 & 10.90 \\
\hline Zero debris and not burned & 362.48 & 45.18 & 174.91 & 21.09 & 275.39 & 29.55 \\
\hline Zero debris not burned and not seeded (control) & 362.48 & 45.18 & 362.48 & 45.18 & 362.48 & 45.18 \\
\hline \multicolumn{7}{|l|}{2001 No treatment $\times$ seed mix interaction } \\
\hline Chip & 12.62 & 4.14 & & & & \\
\hline Pile & 11.47 & 5.54 & & & & \\
\hline Broadcast burn & 208.33 & 7.66 & & & & \\
\hline Chip with burn & 97.80 & 15.25 & & & & \\
\hline Pile with burn & 99.97 & 10.64 & & & & \\
\hline Zero debris and not burned (control) & 186.22 & 11.81 & & & & \\
\hline
\end{tabular}


Table 4. Grass height and grass biomass on the Hilger Hereford ranch near Helena, Montana. Grass height was measured with a Friedman's nonparametric rank test, so standard errors are not given. The bolded height values indicate significance from the control (zero debris, not burned, and not seeded). Biomass in 1999 was also analyzed via a Friedman's nonparametric rank test. In 2000 and 2001, biomass was analyzed with a mixed procedure in SAS. Standard errors are given, and the bolded numbers represent a significant difference from the control. In 2000 and 2001, there was not a treatment $\times$ seed mix interaction, and the treatments were compared to the zero-debris and not-burned control.

\begin{tabular}{|c|c|c|c|c|}
\hline Treatment and year & $\begin{array}{l}\text { Not sown } \\
\text { height }(\mathrm{cm})\end{array}$ & & $\begin{array}{l}\text { Exotic sown } \\
\text { height }(\mathrm{cm})\end{array}$ & $\begin{array}{l}\text { Native sown } \\
\text { height }(\mathrm{cm})\end{array}$ \\
\hline \multicolumn{5}{|l|}{1999} \\
\hline Chip & 23.11 & & 8.21 & 9.21 \\
\hline Pile & 32.37 & & 15.25 & 26.92 \\
\hline Broadcast burn & 17.45 & & 9.92 & 7.23 \\
\hline Chip with burn & 9.83 & & 8.96 & 9.51 \\
\hline Pile with burn & 4.30 & & 7.57 & 7.61 \\
\hline Zero debris and not burned & 9.08 & & 13.88 & 11.33 \\
\hline Zero debris not burned and not seeded (control) & 9.08 & & 9.08 & 9.08 \\
\hline \multicolumn{5}{|l|}{2000} \\
\hline Chip & 24.67 & & 10.57 & 23.85 \\
\hline Pile & 39.33 & & 21.46 & 55.83 \\
\hline Broadcast burn & 29.36 & & 30.29 & 25.25 \\
\hline Chip with burn & 23.65 & & 35.88 & 21.45 \\
\hline Pile with burn & 20.23 & & 33.08 & 21.05 \\
\hline Zero debris and not burned & 8.23 & & 22.26 & 12.38 \\
\hline Zero debris not burned and not seeded (control) & 8.23 & & 8.23 & 8.23 \\
\hline \multicolumn{5}{|l|}{2001} \\
\hline Chip & 37.50 & & 30.86 & 23.00 \\
\hline Pile & 36.40 & & 37.10 & 36.30 \\
\hline Broadcast burn & 32.71 & & 45.79 & 31.20 \\
\hline Chip with burn & 23.20 & & 48.36 & 27.10 \\
\hline Pile with burn & 16.88 & & 42.49 & 25.03 \\
\hline Zero debris and not burned & 11.64 & & 25.39 & 15.08 \\
\hline Zero debris not burned and not seeded (control) & 11.64 & & 11.64 & 11.64 \\
\hline & Biomass $\left(\mathrm{g} \cdot \mathrm{m}^{-2}\right)$ & SE & Biomass $\left(\mathrm{g} \cdot \mathrm{m}^{-2}\right)$ & Biomass $\left(\mathrm{g} \cdot \mathrm{m}^{-2}\right)$ \\
\hline \multicolumn{5}{|l|}{1999} \\
\hline Chip & 4.36 & & 2.65 & 0.45 \\
\hline Pile & 0.45 & & 0.00 & 2.44 \\
\hline Broadcast burn & 4.39 & & 1.79 & 2.17 \\
\hline Chip with burn & 0.08 & & 7.27 & 3.99 \\
\hline Pile with burn & 0.00 & & 1.12 & 1.87 \\
\hline Zero debris and not burned & 9.80 & & 9.74 & 8.67 \\
\hline Zero debris not burned and not seeded (control) & 9.80 & & 9.80 & 9.80 \\
\hline \multicolumn{5}{|l|}{2000 No treatment $\times$ seed mix interaction } \\
\hline Chip & 5.37 & 4.92 & & \\
\hline Pile & 4.47 & 2.69 & & \\
\hline Broadcast burn & 17.69 & 2.95 & & \\
\hline Chip with burn & 18.90 & 5.70 & & \\
\hline Pile with burn & 12.98 & 4.73 & & \\
\hline Zero debris and not burned (control) & 11.23 & 1.46 & & \\
\hline \multicolumn{5}{|l|}{2001 No treatment $\times$ seed mix interaction } \\
\hline Chip & 8.64 & 3.92 & & \\
\hline Pile & 5.24 & 2.96 & & \\
\hline Broadcast burn & 93.12 & 17.24 & & \\
\hline Chip with burn & 64.48 & 11.72 & & \\
\hline Pile with burn & 66.72 & 18.36 & & \\
\hline Zero debris and not burned (control) & 20.00 & 4.04 & & \\
\hline
\end{tabular}


Table 5. Percent composition by life form among the burn treatments on the Hilger Hereford Ranch near Helena, Montana, in 2001. Cheatgrass was significantly lower in all of the exotic-seeded treatments compared with the nonseeded treatments indicated by the bold numbers. The statistical test was performed using the nonparametric Friedman's rank test and the standard errors are not given $(\alpha=0.05)$.

\begin{tabular}{|c|c|c|c|c|}
\hline \multirow[b]{2}{*}{ Treatment } & \multirow[b]{2}{*}{ Species } & \multicolumn{3}{|c|}{ Percentage of species composition } \\
\hline & & Not seeded & Exotic seeded & Native seeded \\
\hline \multirow[t]{7}{*}{ Broadcast burn } & Cheatgrass & 59.05 & 10.54 & 19.00 \\
\hline & Forb & 28.82 & 14.33 & 11.86 \\
\hline & Grass & 25.50 & 70.88 & 74.16 \\
\hline & Moss & 0.00 & 0.00 & 0.00 \\
\hline & Ponderosa pine & 0.00 & 0.00 & 0.00 \\
\hline & Sedge & 0.00 & 0.00 & 0.00 \\
\hline & Shrub & 0.00 & 0.00 & 0.00 \\
\hline \multirow[t]{7}{*}{ Chip with burn } & Cheatgrass & 59.05 & 10.54 & 19.00 \\
\hline & Forb & 61.46 & 5.32 & 6.93 \\
\hline & Grass & 22.92 & 89.11 & 82.32 \\
\hline & Moss & 0.00 & 0.00 & 0.00 \\
\hline & Ponderosa pine & 0.00 & 0.00 & 0.00 \\
\hline & Sedge & 0.00 & 0.00 & 0.00 \\
\hline & Shrub & 0.00 & 0.00 & 0.00 \\
\hline \multirow[t]{7}{*}{ Pile with burn } & Cheatgrass & 59.05 & 10.54 & 19.00 \\
\hline & Forb & 46.57 & 12.28 & 14.45 \\
\hline & Grass & 7.81 & 82.70 & 59.63 \\
\hline & Moss & 0.00 & 0.00 & 0.00 \\
\hline & Ponderosa pine & 0.00 & 0.00 & 0.00 \\
\hline & Sedge & 0.00 & 0.00 & 0.00 \\
\hline & Shrub & 0.00 & 0.00 & 0.00 \\
\hline \multirow[t]{7}{*}{ Zero debris and not burned } & Cheatgrass & 59.05 & 10.54 & 19.00 \\
\hline & Forb & 21.18 & 26.40 & 22.90 \\
\hline & Grass & 37.84 & 63.43 & 64.94 \\
\hline & Moss & 40.98 & 3.56 & 11.80 \\
\hline & Ponderosa pine & 0.00 & 0.00 & 0.36 \\
\hline & Sedge & 0.00 & 0.00 & 0.00 \\
\hline & Shrub & 0.00 & 0.00 & 0.00 \\
\hline
\end{tabular}

the zero-debris and not-burned treatment in biomass and cover (data not shown). Other plant life forms also occurred on the burned and control plots (Table 5) but did not make up as much of the community composition as the grasses on the seeded plots, whereas the reverse occurred in the nonseeded plots. For example, forbs made up a large portion of the community composition in the nonseeded treatments.

\section{Ponderosa Pine Recruitment}

During the 3-year study period, natural ponderosa pine recruitment was very sparse. The not-burned woody-debris treatments and the zero-debris and not-burned treatment were the only treatments with ponderosa pine recruitment. The pile treatment had a mean recruitment of $0.58,0$, and 1.67 ponderosa pine seedlings $\cdot \mathrm{m}^{-2}$ in the exotic, native, and nonseeded plots, respectively. The chip treatment had an average seedling recruitment of $0.60,0.76$, and 0 seedlings $\cdot \mathrm{m}^{-2}$ in the exotic, native, and nonseeded plots, respectively. These small recruitment amounts were not different from the zero-debris and not-burned treatment, which had a mean seedling recruitment of $0.04,0.56$, and 0.16 seedlings $\cdot \mathrm{m}^{-2}$ in the exotic, native, and nonseeded plots, respectively. No ponderosa pine recruitment occurred in the burned treatments during the study (Table 5).

\section{Soil Moisture}

Percent of soil moisture was consistently higher in the pile and chip treatments compared with the zero-debris and not-burned treatments regardless of seeding (Table 6). Percent soil moisture in the woody debris treatments was an average $9.18 \%$, which was $4.49 \%$ higher than the zero-debris and not-burned treatment, with an average soil moisture percentage of $4.69 \%$. At no time did percent soil moisture in the other treatments exceed or drop below the soil moisture percent in the zerodebris and not-burned treatments regardless of seeding.

\section{Soil Surface Temperature}

Spring and early summer maximum daily soil surface temperatures (year 2001) in the pile treatment were consistently cooler $\left(28.84^{\circ} \mathrm{C}\right)$ compared with the zero-debris and not-burned treatments $\left(41.9^{\circ} \mathrm{C}\right)$ regardless of seeding (Table 6). Soil surface temperatures in the rest of the treatments were not different from the zero-debris and not-burned treatments regardless of seeding. 
Table 6. Soil surface temperature $\left({ }^{\circ} \mathrm{C}\right)$ and percent soil moisture (0-5$\mathrm{cm}$ depth) among the treatments on the Hilger Hereford ranch near Helena, Montana. The standard errors are given and represent $1 \mathrm{SE}$ from the means. The bolded numbers represent a significant difference from the control $(\alpha=0.05)$. There was not a significant treatment $\times$ seed mix interaction for these analyses so the control is the zero-debris and notburned treatment.

\begin{tabular}{|c|c|c|}
\hline Treatment and month & Maximum temperature $\left({ }^{\circ} \mathrm{C}\right)$ & SE \\
\hline \multicolumn{3}{|l|}{ June no treatment $\times$ seed mix interaction } \\
\hline Chip & 28.06 & 0.34 \\
\hline Pile & 21.01 & 0.21 \\
\hline Broadcast burn & 28.10 & 0.59 \\
\hline Chip with burn & 33.79 & 0.48 \\
\hline Pile with burn & 33.30 & 0.48 \\
\hline Zero debris and not burned (control) & 31.81 & 0.64 \\
\hline \multicolumn{3}{|l|}{ July no treatment $\times$ seed mix interaction } \\
\hline Chip & 47.50 & 0.86 \\
\hline Pile & 36.67 & 0.61 \\
\hline Broadcast burn & 51.42 & 0.78 \\
\hline Chip with burn & 51.26 & 0.52 \\
\hline Pile with burn & 54.81 & 0.14 \\
\hline Zero debris and not burned (control) & 51.99 & 0.26 \\
\hline \multicolumn{3}{|l|}{ August no treatment $\times$ seed mix interaction } \\
\hline Chip & 49.42 & 0.38 \\
\hline Pile & 40.61 & 0.99 \\
\hline Broadcast burn & 49.99 & 0.77 \\
\hline Chip with burn & 49.60 & 1.14 \\
\hline Pile with burn & 50.92 & 0.26 \\
\hline \multirow[t]{2}{*}{ Zero debris and not burned (control) } & 48.51 & 0.75 \\
\hline & Soil moisture (\%) & SE \\
\hline \multicolumn{3}{|l|}{1999 no treatment $\times$ seed mix interaction } \\
\hline Chip & 10.06 & 0.35 \\
\hline Pile & 9.68 & 0.38 \\
\hline Broadcast burn & 6.45 & 0.24 \\
\hline Chip with burn & 6.67 & 0.35 \\
\hline Pile with burn & 5.84 & 0.10 \\
\hline Zero debris and not burned (control) & 5.69 & 0.13 \\
\hline \multicolumn{3}{|l|}{2000 no treatment $\times$ seed mix interaction } \\
\hline Chip & 7.03 & 0.29 \\
\hline Pile & 6.74 & 0.14 \\
\hline Broadcast burn & 3.78 & 0.14 \\
\hline Chip with burn & 3.75 & 0.14 \\
\hline Pile with burn & 3.57 & 0.28 \\
\hline Zero debris and not burned (control) & 3.48 & 0.11 \\
\hline \multicolumn{3}{|l|}{2001 no treatment $\times$ seed mix interaction } \\
\hline Chip & 10.16 & 0.31 \\
\hline Pile & 11.41 & 0.38 \\
\hline Broadcast burn & 5.61 & 0.26 \\
\hline Chip with burn & 5.28 & 0.35 \\
\hline Pile with burn & 4.40 & 0.33 \\
\hline Zero debris and not burned (control) & 4.90 & 0.28 \\
\hline
\end{tabular}

Disposing of woody debris following conifer removal by common methods tested in this study does not appear to hinder grass seedling emergence. Grass emergence is governed by many factors, including the presence of safe sites (Harper 1977; Baskin and Baskin 1998). In our study, grass emergence in the treatments occurred throughout the growing season in 1999 (emergence was negligible in subsequent years). There were no differences between the treatments and the zero-debris, notburned and not-seeded treatment (control) except for the nativeseeded chip-with-burn treatment in August. Maximum summer soil surface temperatures can exceed $50^{\circ} \mathrm{C}$ in the treatments even when shaded by established grasses (Table 6). With the exception of the nonburned woody-debris treatments, soil moisture was limiting, often being held at a tension far below the $-1.5-\mathrm{MPa}$ wilting point (Fig. 1). Grass emergence and seedling growth in the treatments, especially the chip-with-burn treatment, in spite of limiting soil moisture and potentially lethal soil surface temperatures, suggests that the woody-debris disposal practices tested in this study do not hinder grass emergence and provide safe sites for germination and emergence.

Hermann and Chilcote (1965) reported that soil moisture is retained for a longer time near the bottom of charcoal particles and in the crevices of heavy-textured soils. In addition, Smith and Capelle (1992) indicated that crevices formed where clods or rocks interface with the soil surface create microsites where moisture is retained and provide seedling roots an opportunity to become established. In this study, the broadcast-burn and chip-with-burn treatments were incomplete burns in which charcoal and unconsumed woody debris remained on the surface (Law 2004). The charcoal and debris on the soil surface of the broadcast-burn and chip-with-burn treatments as well as the nonburned woody-debris treatments likely provided variation in microrelief, which in turn offered a beneficial environment for seedling emergence. Although we measured soil water potential near the soil surface, it is apparent that the seeds may have imbibed microsite water that we were unable to measure. Future studies should measure microrelief variation of the soil surface.

Following emergence, grass establishment was also not impaired by the woody-debris disposal treatments tested in this study. Grass cover and density, initially less than control levels, increased to the level of the control by the second growing season after treatment, especially in the burn treatments. In addition, grass height exceeded the control levels in most of the treatments 2 years postburn and continued to exceed the control levels 3 years postburn especially in the seeded treatments. Grass production (biomass) in most of the treatments during the study was not different from the zerodebris and not-burned treatments, even as soon as a few months after treatment. Furthermore, grass production in the broadcast-burn treatment was nearly 5 times higher than the zero-debris and not-burned treatment 3 years after the burn. Grass production was also higher in the broadcast-burn treatment when compared with the 2 nonburned woody-debris treatments 3 years after treatment. Grass cover and density were also greater in the broadcast-burn and chip-with-burn treatments compared with the 2 nonburned woody-debris treatments 3 years after treatment. Relatively low grass pro- 

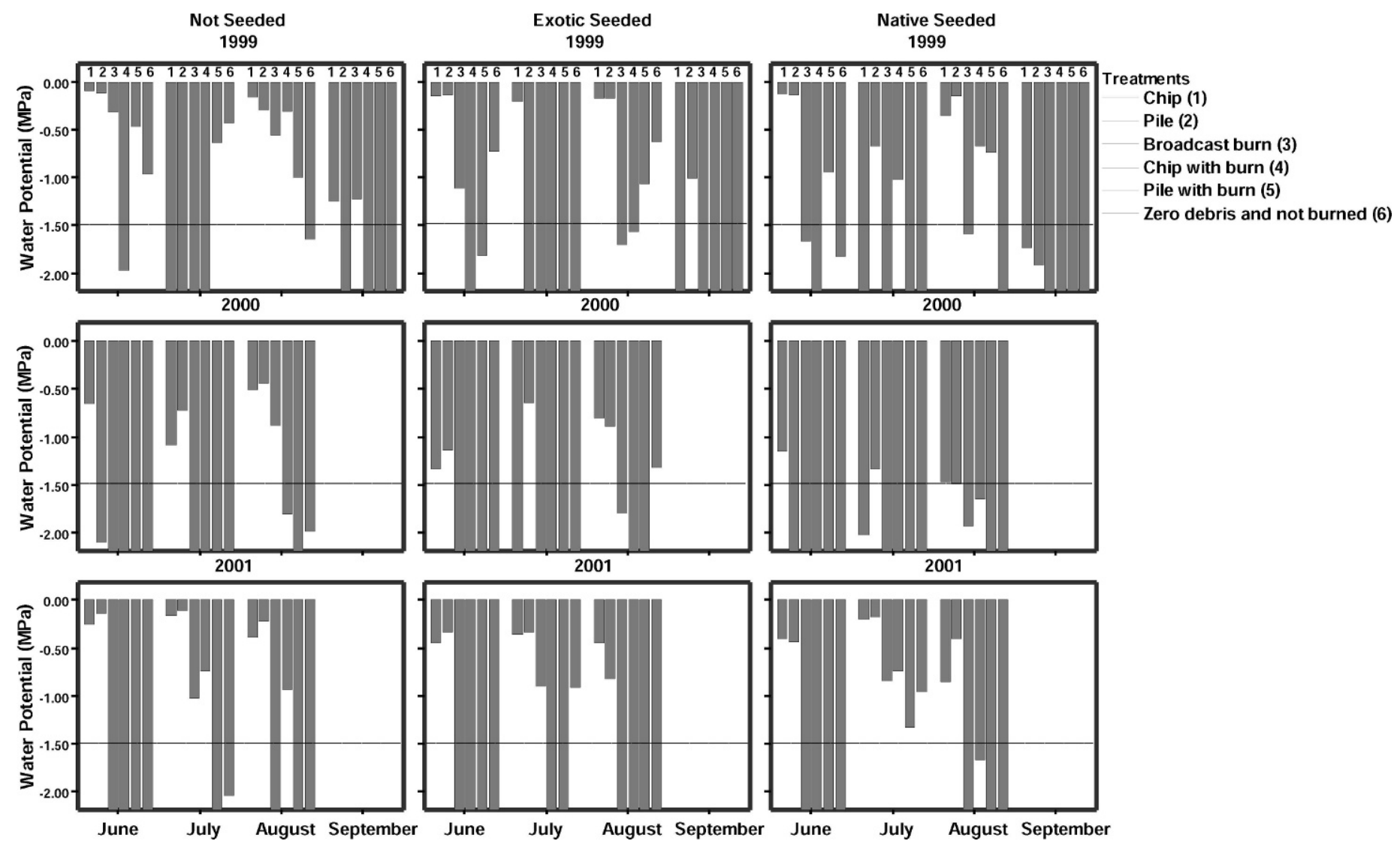

Figure 1. Soil water potential among the treatments at the Hilger Hereford Ranch near Helena, Montana. The bars in the graph are ordered as noted in the legend; left to right are the chip, pile, broadcast-burn, chip-with-burn, pile-with-burn, and zero-debris and not-burned treatments. Each year of the study is represented as well as each seed mix. The horizontal line represents the conventional permanent wilting point of $-1.5 \mathrm{MPa}$.

duction, in the control treatments, even after conifer removal indicates a low-productive, semiarid site where soil moisture is a limiting resource. The results of this study did not show a statistically significant increase in soil moisture as a result of burning the residual woody debris. Nevertheless, grass production increased from 1999 to 2001 on the burn treatments, which implies that soil water was used by grasses and may have been influenced by the treatments. Increased inorganic nitrogen associated with burning ponderosa pine forests (Kovacic et al. 1986; Covington and Sackett 1992; Monleon et al. 1997; DeLuca and Zouhar 2000) may also have enhanced grass cover, density, height, and biomass in the burn treatments (especially the broadcast-burn treatment) compared with the control and woody-debris treatments.

Ultimately, 2 factors controlled the results of this study. First, seeds needed specific conditions for germination. It appears that the treatments may have created microsite heterogeneity benefiting grass seedling emergence. Second, newly established seedlings required an environment that promoted growth and survival. Broadcast-burning residual woody debris showed the best results. The nonburned woody-debris treatments generally provided higher soil water and cooler soil surface temperatures when compared with the zero-debris and not-burned treatment. Nevertheless, mechanical impedance (Grubb 1977; Fowler 1986) or poor nutrient availability may have prevented the measured grass variables, especially culm density, from in- creasing to or beyond control levels. Low light and temperatures associated with litter (Willms et al. 1986) may negatively affect tiller production (Mitchell 1953; Langer 1963; Laude 1972). Willms et al. (1986) suggests that removing litter results in shorter plants, which is likely caused by more light, warmer temperatures, and lower soil moisture. Grass height growth was relatively high and tiller density was low in the woodydebris treatments especially the pile treatment. This may have been a result of a combination of shading, lower temperatures, and higher soil moisture.

At first glance, it appears that seeding with native or exotic seed mixes did not contribute to the success of the treatments. With the exception of grass height, no significant interaction was detected between the treatments and seed mixes for grass cover, density, or biomass 3 years postburn. Nevertheless, many of the grasses among both of the seed mixes, such as mountain brome and intermediate wheatgrass, performed well in the burn treatments. In addition, there are indications that vegetative growth of nonseeded grasses and other life forms, such as forbs, masked the results (Table 5). For example, 3 years after the treatment, percent cheatgrass composition was statistically higher in all of the nonseeded burn treatments compared with the exotic-seeded burn treatments (no significant treatment $\times$ seed mix interaction). It appears that significant cheatgrass growth in the nonseeded burn treatments contributed to grass production, whereas the seeded burn 
treatments (especially the exotic-seeded treatments) had lower cheatgrass percentages and higher desirable-grass percentages. Therefore, broadcast burning of residual woody debris and seeding with desirable grasses appears to be the best mechanism for disposing of woody debris while increasing desirable-grass emergence and establishment. Ultimately, a well-established grass community will likely compete well for limited soil moisture, preventing ponderosa pine recruitment and invasion by exotic species, such as cheatgrass.

\section{IMPLICATIONS}

Restoring desirable grasses to rangelands following conifer removal is necessary to improve rangeland productivity and ponderosa pine and exotic species control. A healthy bunchgrass community will likely outcompete ponderosa pine seedlings for soil moisture and occupy available niches that otherwise would be occupied by exotic species, such as cheatgrass. Managers and landowners are often financially limited and need restoration options that will provide the best mechanism for reestablishing grasses in semiarid sites. The results of this study suggest that excess woody debris following conifer removal can be used to improve desirable grass emergence, growth, and survival. Several options are available, ranging from hand-piling and mulching debris to lop-and-scatter methods followed by a broadcast burn. Our results suggest that, of the options tested, simply scattering and burning woody debris combined with reseeding is the best option for improving desirable grass emergence, growth, and survival.

\section{ACKNOWLEDGMENTS}

The authors would like to acknowledge Cathy Campbell, D. J. Bakken, Jeff Knudsen, and Kirk Knudsen for assistance with field work. The authors would like to express gratitude to Dr Rosemary Pendleton for her review and comments that greatly improved this paper and Dr Rudy King for statistical advice.

\section{LITERATURE CITED}

Allen, E. B., And M. F. Allen. 1986. Water relations of xeric grasses in field: interactions of mycorrhizas and competition. New Phytologist 104:559-571.

ARno, S. F. 1996. The concept: restoring ecological structure and process in ponderosa pine forests. In: C. C. Hardy and S. F. Arno [EDS.]. The use of fire in forest restoration. Ogden, UT: US Department of Agriculture, Forest Service, Intermountain Research Station, General Technical Report INT-341. 86 p.

BASKIN, C. C., AND J. M. BASKIN. 1998. Seeds ecology, biogeography, and evolution of dormancy and germination. San Diego, CA: Academic Press. 625 p.

Benard, A., and P. van Elteren. 1953. A generalization of the method of $m$ rankings. Indagationes Mathematicae 15:358-369.

BerTness, M. D. 1991a. Interspecific interactions among high marsh perennials in a New England salt marsh. Ecology 72:125-137.

BerTness, M. D. 1991b. Zonation of Spartina patens and Spartina alterniflora in a New England salt marsh. Ecology 72:138-148.

Bolen, E. G. 1998. Ecology of North America. New York, NY: John Wiley and Sons. 464 p.

Bonнam, C. D. 1989. Measurements for terrestrial vegetation. New York, NY: John Wiley and Sons. $338 \mathrm{p}$.

Caldwell, M. M., D. M. Eissenstat, and J. H. Richards. 1985. Competition for phosphorus: differential uptake from dual-isotope-labeled soil interspaces between shrub and grass. Science 229:384-386.
Covington, W. W., And S. S. Sacketr. 1992. Soil mineral nitrogen changes following prescribed burning in ponderosa pine. Forest Ecology and Management $54: 175-191$.

DaubenmiRe, R. 1959. A canopy-coverage method of vegetational analysis. Northwest Science 33:43-64.

DaubenMIRE, R. 1968. Soil moisture in relation to vegetation distribution in the mountains of northern Idaho. Ecology 49:431-438.

Davis, M. A., K. J. Wrage, and P. B. Reich. 1998. Competition between tree seedlings and herbaceous vegetation: support for a theory of resource supply and demand. Journal of Ecology 86:652-661.

Deluca, T. H., and K. L. Zouhar. 2000. Effects of selection harvest and prescribed fire on the soil nitrogen status of ponderosa pine forests. Forest Ecology and Management 138:263-271.

Duan, N. 1983. Smearing estimate: a nonparametric retransformation method. Journal of the American Statistical Association 78(383):605-610.

Dyksterhuis, E. J., and E. M. Schmutz. 1947. Natural mulches or "litter" of grasslands, with kinds and amount on a southern prairie. Ecology 28:163-179.

Eissenstat, D. M., and M. M. Caldwell. 1988. Competitive ability is linked to rates of water extraction: a field study of two arid land tussock grasses. Oecologia 75:1-7.

Eluıson, A. M. 1987. Effects of competition, disturbance, and herbivory on Salicornia europaea. Ecology 68:576-586.

Fonteyn, P. J., and B. E. Mahall. 1981. An experimental analysis of structure in a desert plant community. Journal of Ecology 69:883-896.

FowLER, J. L. 1986. Microsite requirements for germination and establishment of three grass species. American Midland Naturalist 115:131-145.

Fulé, P. Z., C. Mchugh, T. A. Heinlein, and W. W. Covington. 2001. Potential fire behavior is reduced following forest restoration treatments. In: R. K. Vance, C. B. Edminster, W. W. Covington, and J. A. Blake [EDs.]. Ponderosa pine ecosystems restoration and conservation: steps toward stewardshipProceedings. Ogden, UT: US Department of Agriculture, Forest Service, Rocky Mountain Research Station, RMRS-P-22. 188 p.

Gardner, W. H. 1986. Water content. In: A. Klute [ED.]. Methods of soil analysis: Part I—Physical and mineralogical methods. Soil Science Society of America book series no. 5. Madison, WI: Soil Science Society of America. p. 493-544.

GRIFFIN, J. R. 1982. Pine seedlings, native ground cover, and Lolium multiflorum on the Marble-Cone burn, Santa Lucia Range, California. Madrono 29(3):177-188.

GRUBB, P. J. 1977. The maintenance of species richness in plant communities: the importance of the regeneration niche. Biological Review 52:107-145.

Gruell, G. E., J. K. Brown, And C. L. Bushey. 1986. Prescribed fire opportunities in grasslands invaded by Douglas-fir: State-of-the-art guidelines. Ogden, UT: US Department of Agriculture, Forest Service, Intermountain Research Station, General Technical Report INT-198. 19 p.

Gupta, S. C., W. E. Larson, and R. R. Allmaras. 1984. Predicting soil temperature and soil heat flux under different tillage-surface residue conditions. Soil Science Society of America Journal 48:223-232.

HarpeR, J. L. 1977. Population biology of plants. New York, NY: Academic Press. $892 \mathrm{p}$.

Hermann, R. K., and W. W. Chilcote. 1965. Effect of seedbeds on germination and survival of Douglas-fir. Corvallis, OR: Oregon State University, Agricultural Experiment Station, Forest Research Laboratory, Resource paper No. 4.28 p.

Herr, D. G., L. C. Duchesne, and R. J. Reader. 1999. Effects of soil organic matter, moisture, shading and ash on white pine (Pinus strobes L.) seedling emergence. New Forests 18:219-230.

Hollander, M., and D. A. Wolfe. 1999. Nonparametric statistical methods, 2nd ed. New York, NY: John Wiley and Sons. $787 \mathrm{p}$.

HuBBaRd, R. L. 1957. The effects of plant competition on the growth and survival of bitterbrush seedlings. Journal of Range Management 10:135-137.

Kolb, P. F., And R. Robberecht. 1996. Pinus ponderosa seedling establishment and the influence of competition with the bunchgrass Agropyron spicatum. International Journal of Plant Science 157(4):509-515.

KolleR, D. 1972. Environmental control of seed germination. In: T. T. Kozlowski [ED.]. Seed biology. Volume 2. New York, NY: Academic Press. p. 1-101. 
Kovacic, D. A., D. M. Swift, J. E. Ellis, and T. E. Hakonson. 1986. Immediate effects of prescribed burning on mineral soil nitrogen in ponderosa pine of New Mexico. Soil Science 141:71-76.

LAngeR, R. H. M. 1963. Tillering in herbage grasses. Herbage Abstracts 33:141-148.

LAUDE, H. M. 1972. External factors affecting tiller development. In: V. B. Youngner and C. M. McKell [EDS.]. The biology and utilization of grasses. New York, NY: Academic Press. p. 146-154.

Lauenroth, W. K., O. E. Sala, D. P. Coffin, and T. B. Kirchner. 1994. The importance of soil water in the recruitment of Bouteloua gracilis in the short grass steppe. Ecological Applications 4:741-749.

LAW, D. J. 2004. Forest and range ecotone restoration in central Montana [dissertation]. Missoula, MT: University of Montana College of Forestry and Conservation. 209 p. Available from: University of Montana Library, Missoula, MT.

Lincoln, R. J., G. A. Boxshall, and P. F. Clark. A dictionary of ecology, evolution and systematics. Cambridge, UK: Cambridge University Press. 298 p.

Mack, G. A., AND J. H. SkilıINGs. 1980. A Friedman-type rank test for main effects in a two-factor ANOVA. Journal of the American Statistical Association 75:947-951.

Malik, A. U., C. H. Gimingham, and A. A. Rahman. 1984. Ecological effects of heather burning, I: water infiltration, moisture retention and porosity of surface soil. Journal of Ecology 72:767-776.

Metcalfe, W. S., A. M. Ellison, and M. D. Bertness. 1986. Survivorship and spatial development of Spartina alterniflora Loisel. (Gramineae) seedlings in a New England salt marsh. Annals of Botany 58:249-258.

MiтcheLL, K. J. 1953. Influence of light and temperature on the growth of ryegrass (Lolium spp.), II: the control of lateral bud development. Physiologia Plantarum 6:425-443

Monleon, V. J., K. Cromack, and J. D. Landsberg. 1997. Short- and long-term effects of prescribed underburning on nitrogen availability in ponderosa pine stands in central Oregon. Canadian Journal of Forest Resources 27:369-378.
Norwood, P. K., A. R. Sampson, K. McCarroll, and R. Staum. 1989. A multiple comparisons procedure for use in conjunction with the Benard-van Elteren test. Biometrics 45:1175-1182.

Pennings, S. C., and R. M. Callaway. 1992. Salt marsh plant zonation: the relative importance of competition and physical factors. Ecology 73(2): 681-690.

Phillips, R. E., and S. H. Phillips. 1984. No-tillage agriculture: principles and practices. New York, NY: Van Nostrand Reinhold. 306 p.

Raynal, D. J., and F. A. Bazzaz. 1973. Establishment of early successional plant populations on forest and prairie soil. Ecology 54:1335-1341.

Robberecht, R., B. E. Mahall, and P. S. Nobel. 1983. Experimental removal of intraspecific competitors-effects on water relations and productivity of a desert bunchgrass, Hilaria rigida. Oecologia 60:21-24.

Sala, O. E., and W. K. LaUenRoth. 1982. Small rainfall events: an ecological role in semiarid regions. Oecologia 53:301-303.

Smith, M., and J. Capelle. 1992. Effects of soil surface microtopography and litter cover on germination, growth and biomass production of chicory (Cichorium intybus L.). American Midland Naturalist 128:246-253.

Vance, N. C., and S. W. Running. 1985. Summer climatic influences on Pinus ponderosa planted on mined lands in eastern Montana. Reclamation and Revegetation Research 4:129-143.

WALSH, R. P. D., AND P. J. VolGt. 1977. Vegetation litter: an underestimated variable in hydrology and geomorphology. Journal of Biogeography 4:253-274.

Weaver, J. E., and N. W. Rowland. 1952. Effect of excessive natural mulch on the development, yield, and structure of native grassland. Botanical Gazette 114:1-19.

Willms, W. D., S. Smoliak, and A. W. Balley. 1986. Herbage production following litter removal on Alberta native grasslands. Journal of Range Management $39: 536-539$ 